\title{
Induction of erythroferrone in healthy humans by micro-dose recombinant erythropoietin or high-altitude exposure
}

Haematologica 2021

Volume 106(2):384-390

\section{Correspondence: \\ GAETANO CAIRO \\ gaetano.cairo@unimi.it \\ PAUL ROBACH \\ paul.robach@ensm.sports.gouv.fr \\ Received: July 31, 2019. \\ Accepted: January 2, 2020. \\ Pre-published: January 9, 2020.}

https://doi.org/10.3324/haematol.2019.233874

(C)2021 Ferrata Storti Foundation

Material published in Haematologica is covered by copyright. All rights are reserved to the Ferrata Storti Foundation. Use of published material is allowed under the following terms and conditions:

https://creativecommons.org/licenses/by-nc/4.0/legalcode. Copies of published material are allowed for personal or internal use. Sharing published material for non-commercial purposes is subject to the following conditions:

https://creativecommons.org//icenses/by-nc/4.0/legalcode, sect. 3. Reproducing and sharing published material for commercial purposes is not allowed without permission in writing from the publisher.

\section{Paul Robach, ${ }^{1 *}$ Elena Gammella, ${ }^{2 *}$ Stefania Recalcati, ${ }^{2}$ Domenico Girelli, ${ }^{3}$ Annalisa Castagna, ${ }^{3}$ Matthieu Roustit, ${ }^{4}$ Carsten Lundby, ${ }^{5}$ Anne-Kristine Lundby, ${ }^{5}$ Pierre Bouzat, ${ }^{4}$ Samuel Vergès, ${ }^{6}$ Guillaume Séchaud, ${ }^{4}$ Pierluigi Banco, ${ }^{4}$ Mario Uhr, ${ }^{7}$ Catherine Cornu, ${ }^{8}$ Pierre Sallet ${ }^{9}$ and Gaetano Cairo ${ }^{2}$}

${ }^{1}$ National School for Mountain Sports, Chamonix, France; ${ }^{2}$ Department of Biomedical Sciences for Health, University of Milan, Italy; ${ }^{3}$ Department of Medicine, University of Verona, Italy; ${ }^{4}$ Grenoble Alpes University Hospital, Grenoble, France; ${ }^{5}$ Center for Physical Activity Research, University Hospital, Copenhagen, Denmark; ${ }^{6 H P 2}$ Laboratory, U1042, Grenoble Alpes University, INSERM, Grenoble, France; 'Department of Hematology Synlab-Suisse, Lugano, Switzerland; ${ }^{8}$ Hospices Civils de Lyon INSERM CIC1407/UMR5558, Hôpital Louis Pradel, Bron, France and " "Athletes for Transparency" Association, Lyon, France

*PR and EG contributed equally as co-first authors.

\section{ABSTRACT}

1 he erythropoietin (Epo)-erythroferrone (ERFE)-hepcidin axis coordinates erythropoiesis and iron homeostasis. While mouse studies have established that Epo-induced ERFE production represses hepcidin synthesis by inhibiting hepatic BMP/SMAD signaling, evidence for the role of ERFE in humans is limited. To investigate the role of ERFE as a physiological erythroid regulator in humans, we conducted two studies. First, 24 males were given six injections of saline (placebo), recombinant Epo (rhEpo) at a dose of $20 \mathrm{IU} / \mathrm{kg}$ (micro-dose) or rhEpo at $50 \mathrm{IU} / \mathrm{kg}$ (low dose). Second, we quantified ERFE in 22 subjects exposed to high altitude $(3800 \mathrm{~m})$ for $15 \mathrm{~h}$. In the first study, total hemoglobin mass $\left(\mathrm{Hb}_{\text {max }}\right)$ increased after low- but not after micro-dose injections, when compared to the mass after placebo injections. Serum ERFE levels were enhanced by rhEpo, remaining higher than after placebo for $48 \mathrm{~h}$ (micro-dose) or 72 $\mathrm{h}$ (low-dose) after injections. Conversely, hepcidin levels decreased when Epo and ERFE rose, before any changes in serum iron parameters occurred. In the second study, serum Epo and ERFE increased at high altitude. The present results demonstrate that in healthy humans ERFE responds to slightly increased Epo levels not associated with $\mathrm{Hb}_{\operatorname{mas}}$ expansion and downregulates hepcidin in an apparently iron-independent way. Notably, ERFE flags micro-dose Epo, thus holding promise as a novel biomarker of doping.

\section{Introduction}

Erythropoiesis and iron metabolism are tightly linked and an inadequate iron supply to developing erythrocytes results in anemia, a condition affecting a large segment of the world's population. The coordination between erythropoietic activity and iron homeostasis is provided by hepcidin, which controls body iron balance by negatively regulating the activity of the iron exporter, ferroportin. ${ }^{1,2}$ Hepcidin expression is inhibited by iron deficiency and high erythropoietic activity, ${ }^{1,2}$ a response that increases iron availability to meet iron needs for hemoglobin synthesis. Accordingly, we and others have demonstrated that recombinant human erythropoietin (rhEpo) administration to healthy humans is followed by a prompt downregulation of hepcidin. ${ }^{3.5}$ The identification and characterization of erythroferrone (ERFE), a hepcidin-inhibiting factor produced by erythroblasts in response to Epo, provided an additional link between erythropoietic activity and iron homeostasis. ${ }^{6}$ Mouse studies established that ERFE synthesized in response to Epo impairs hepcidin transcription by inhibiting hepatic BMP/SMAD signaling. ${ }^{6,7}$ The 
A

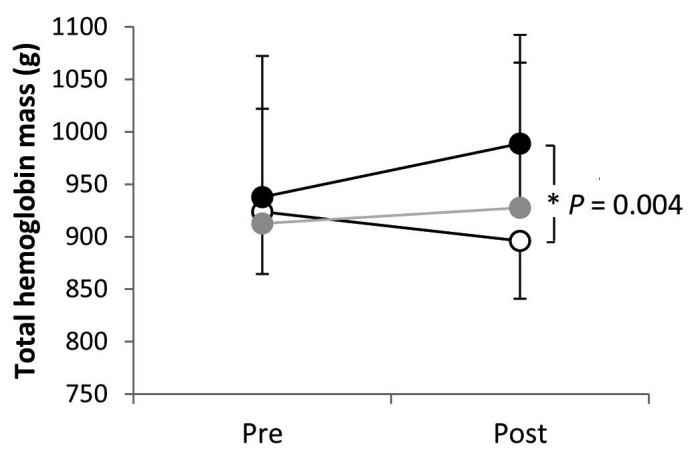

-O-Placebo

- Epo $20 \mathrm{IU} / \mathrm{kg}$

- Epo $50 \mathrm{IU} / \mathrm{kg}$

B

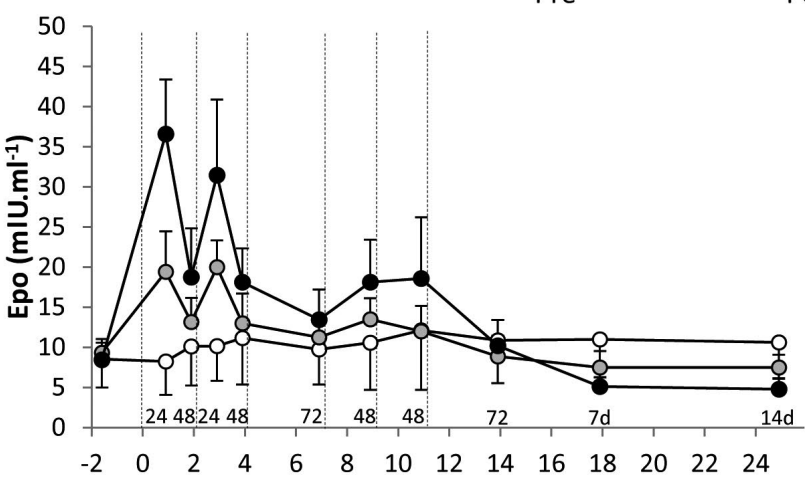

\begin{tabular}{|c|c|c|c|c|c|c|}
\hline & PLA & EPO20 & EPO50 & Group & $\begin{array}{c}\text { Occur } \\
\text { rence }\end{array}$ & G $\times 0$ \\
\hline \multirow{2}{*}{$24 \mathrm{~h}$} & $9.6 \pm$ & $19.2 \pm$ & $34.2 \pm$ & $P=$ & $P=$ & $P=$ \\
& 1.5 & $1.5^{*}$ & $1.4^{*} \ddagger$ & 0.0001 & 0.51 & 0.25 \\
\hline \multirow{2}{*}{$48 \mathrm{~h}$} & 11.2 & $12.4 \pm$ & $18.7 \pm$ & $P=$ & $P=$ & $P=$ \\
& \pm 0.8 & 0.9 & $0.8^{*} \ddagger$ & 0.0001 & 0.99 & 0.97 \\
\hline \multirow{2}{*}{$72 \mathrm{~h}$} & 10.5 & $9.5 \pm$ & $12.1 \pm$ & $P=$ & $P=$ & $P=$ \\
& \pm 0.7 & 0.7 & $0.7^{*} \ddagger$ & 0.04 & 0.07 & 0.08 \\
\hline \multirow{2}{*}{7 days } & 11.2 & $7.0 \pm$ & $5.4 \pm$ & $P=$ & & \\
& \pm 0.7 & $0.7^{*}$ & $0.7^{*}$ & 0.0001 & & \\
\hline \multirow{2}{*}{14 days } & 10.8 & $7.1 \pm$ & $5.0 \pm$ & $P=$ & & \\
& \pm 0.8 & $0.8^{*}$ & $0.8^{*}$ & 0.0001 & & \\
\hline \multicolumn{7}{|c|}{}
\end{tabular}

$$
-2
$$

C

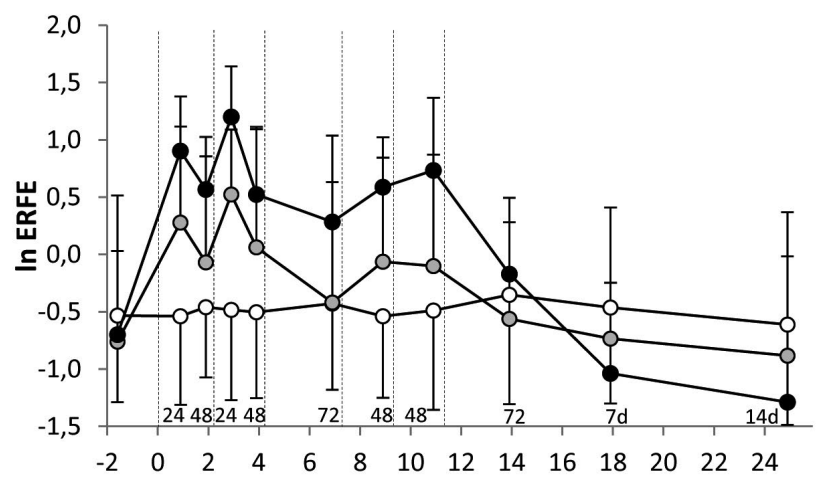

\begin{tabular}{|c|c|c|c|c|c|c|}
\hline & PLA & EPO20 & EPO50 & Group & $\begin{array}{l}\text { Occur } \\
\text { rence }\end{array}$ & $\mathrm{G} \times \mathrm{O}$ \\
\hline $24 \mathrm{~h}$ & $\begin{array}{c}-0.59 \pm \\
0.11\end{array}$ & $\begin{array}{l}0.45 \pm \\
0.10^{*}\end{array}$ & $\begin{array}{c}1.07 \pm \\
0.10^{*} \ddagger\end{array}$ & $\begin{array}{c}P= \\
0.0001\end{array}$ & $\begin{array}{c}P= \\
0.10\end{array}$ & $\begin{array}{c}P= \\
0.69\end{array}$ \\
\hline $48 \mathrm{~h}$ & $\begin{array}{c}-0.59 \pm \\
0.09\end{array}$ & $\begin{array}{l}0.02 \pm \\
0.08^{*}\end{array}$ & $\begin{array}{c}0.62 \pm \\
0.08 * \ddagger\end{array}$ & $\begin{array}{c}P= \\
0.0001\end{array}$ & $\begin{array}{c}P= \\
0.98\end{array}$ & $\begin{array}{c}P= \\
0.97\end{array}$ \\
\hline $72 \mathrm{~h}$ & $\begin{array}{c}-0.49 \pm \\
0.13\end{array}$ & $\begin{array}{l}-0.42 \\
\pm 0.12\end{array}$ & $\begin{array}{c}0.08 \pm \\
0.12^{*} \ddagger\end{array}$ & $\begin{array}{c}P= \\
0.004\end{array}$ & $\begin{array}{c}P= \\
0.23\end{array}$ & $\begin{array}{c}P= \\
0.33\end{array}$ \\
\hline 7 days & $\begin{array}{c}-0.59 \pm \\
0.15\end{array}$ & $\begin{array}{l}-0.65 \\
\pm 0.14\end{array}$ & $\begin{array}{c}-1.01 \pm \\
0.14\end{array}$ & $\begin{array}{c}P= \\
0.09\end{array}$ & & \\
\hline 14 days & $\begin{array}{c}-0.75 \pm \\
0.25\end{array}$ & $\begin{array}{r}-0.79 \\
\pm 0.23\end{array}$ & $\begin{array}{c}-1.26 \pm \\
0.23\end{array}$ & $\begin{array}{c}P= \\
0.26\end{array}$ & & \\
\hline
\end{tabular}

D

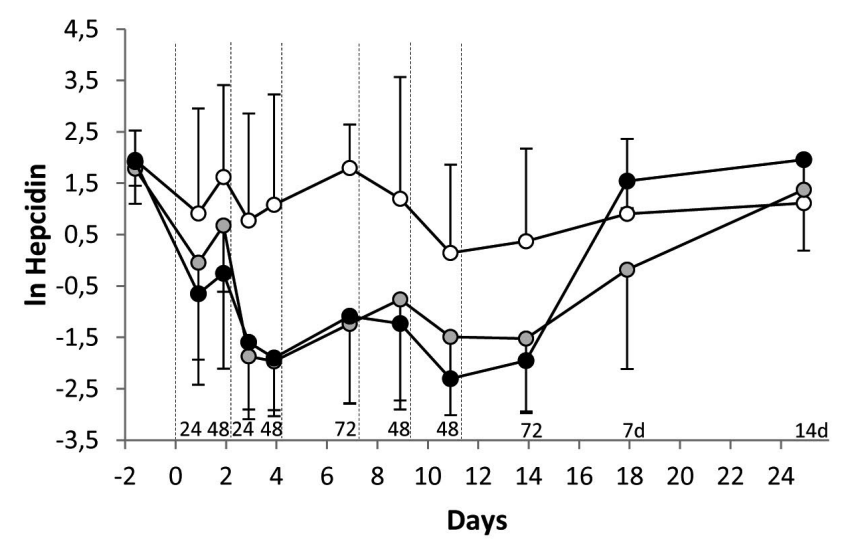

\begin{tabular}{|c|c|c|c|c|c|c|}
\hline & PLA & EPO20 & EPO50 & Group & $\begin{array}{c}\text { Occur } \\
\text { rence }\end{array}$ & G $\times$ O \\
\hline $24 \mathrm{~h}$ & $\begin{array}{c}0.78 \pm \\
0.42\end{array}$ & $\begin{array}{c}-0.85 \pm \\
0.42^{*}\end{array}$ & $\begin{array}{c}-1.16 \pm \\
0.42^{*}\end{array}$ & $\begin{array}{c}P= \\
0.005\end{array}$ & $\begin{array}{c}P= \\
0.05\end{array}$ & $\begin{array}{c}P= \\
0.37\end{array}$ \\
\hline \multirow{2}{*}{$48 \mathrm{~h}$} & $\begin{array}{c}0.95 \pm \\
0.28\end{array}$ & $\begin{array}{c}-0.78 \pm \\
0.28^{*}\end{array}$ & $\begin{array}{c}-1.48 \pm \\
0.29^{*}\end{array}$ & $\begin{array}{c}P= \\
0.0001\end{array}$ & $\begin{array}{c}P= \\
0.000 \\
1\end{array}$ & $\begin{array}{c}P= \\
0.70\end{array}$ \\
\hline $72 \mathrm{~h}$ & $\begin{array}{c}1.04 \pm \\
0.35\end{array}$ & $\begin{array}{c}-1.31 \pm \\
0.35^{*}\end{array}$ & $\begin{array}{c}-1.54 \pm \\
0.35^{*}\end{array}$ & $\begin{array}{c}P= \\
0.0001\end{array}$ & $\begin{array}{c}P= \\
0.04\end{array}$ & $\begin{array}{c}P= \\
0.52\end{array}$ \\
\hline 7 days & $\begin{array}{c}0.85 \pm \\
0.50\end{array}$ & $\begin{array}{c}-0.11 \pm \\
0.50\end{array}$ & $\begin{array}{c}1.52 \pm \\
0.49\end{array}$ & $\begin{array}{c}P= \\
0.09\end{array}$ & & \\
\hline 14 days & $\begin{array}{c}1.13 \pm \\
0.33\end{array}$ & $\begin{array}{c}1.34 \pm \\
0.33\end{array}$ & $\begin{array}{c}1.97 \pm \\
0.33\end{array}$ & $\begin{array}{c}P= \\
0.19\end{array}$ & & \\
\hline
\end{tabular}

Figure 1. Effects of repeated administration of very low to low doses of recombinant human erythropoietin on total hemoglobin mass, erythropoietin, erythroferrone and hepcidin. (A) Total hemoglobin mass $\left(\mathrm{Hb}_{\mathrm{max}}\right.$ ), determined at baseline (Pre) and $72 \mathrm{~h}$ after the last of the six injections (Post) of placebo ( $\mathrm{n}=7$ ), recombinant human erythropoietin (rhEpo) $20 \mathrm{lU} / \mathrm{kg}$ (micro-dose) $(n=7)$ or rhEpo $50 \mathrm{IU} / \mathrm{kg}$ (low dose) $(n=8)$. ANOVA for a significant time $\times$ treatment interaction $(\mathrm{P}=0.049)$. *Indicates a significant difference between low-dose rhEpo and placebo. Data are means \pm standard deviations. Individual $\mathrm{Hb}_{\max }$ values are available in Online Supplementary Figure S1. (B-D) Serum concentrations of erythropoietin (B), erythroferrone (In transformed, $n=7$ for the placebo condition) (C) and hepcidin (In transformed) (D) before, during and after six injections of placebo $(n=8)$, micro-dose rhEpo $(n=8)$ or low-dose rhEpo $(n=8)$. Vertical dotted lines indicate injections. Baselines are means from duplicate blood samples collected on separated days. Blood sampling was repeatedly performed at $24 \mathrm{~h}$ ( 2 occurrences), $48 \mathrm{~h}$ ( 4 occurrences) and $72 \mathrm{~h}$ ( 2 occurrences) after an injection. Additional samples were obtained at 7 and 14 days after the last injection. Numbers above the abscissa line (i.e., 24, 48, $72,7 \mathrm{~d}$ and $14 \mathrm{~d})$ indicate these sampling times, respectively. Data are means \pm standard deviations. For each panel, the inserted table reports estimated marginal means \pm standard errors and P-values for the effect of the group (placebo, micro-dose, low dose), the occurrence (i.e., the number of samples at $24 \mathrm{~h}, 48 \mathrm{~h}, 72 \mathrm{~h}, 7$ days and 14 days, from 1 to 4 ) and the group $\times$ occurrence $(\mathrm{G} \times 0)$ interaction. Multiple comparisons between groups at $24 \mathrm{~h}, 48 \mathrm{~h}$ or $72 \mathrm{~h}$ are reported in each table, *Denotes a difference from placebo and łdenotes a difference from micro-dose rhEPO (see the Online Supplementary Material, Statistical analysis section). Epo: erythropoietin; ERFE: erythroferrone; PLA: placebo. EPO20: recombinant human erythropoietin $20 \mathrm{IU} / \mathrm{kg}$; EPO50: recombinant human erythropoietin $50 \mathrm{IU} / \mathrm{kg}$. 
A

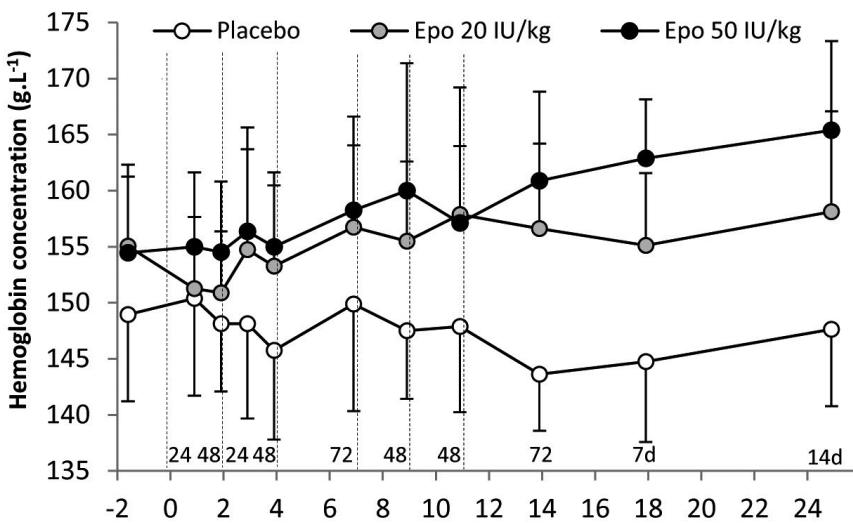

\begin{tabular}{|c|c|c|c|c|c|c|}
\hline & PLA & EPO20 & EPO50 & Group & $\begin{array}{c}\text { Occur } \\
\text { rence }\end{array}$ & $\mathrm{G} \times \mathrm{O}$ \\
\hline \multirow{2}{*}{$24 \mathrm{~h}$} & $\begin{array}{c}153 \pm \\
1.2\end{array}$ & $\begin{array}{c}151 \pm \\
1.2\end{array}$ & $\begin{array}{c}154 \pm \\
1.2\end{array}$ & $\begin{array}{c}P= \\
0.16\end{array}$ & $\begin{array}{c}P= \\
0.52\end{array}$ & $\begin{array}{c}P= \\
0.23\end{array}$ \\
\hline \multirow{2}{*}{$48 \mathrm{~h}$} & $\begin{array}{c}150 \pm \\
0.9\end{array}$ & $\begin{array}{c}153 \pm \\
0.9\end{array}$ & $\begin{array}{c}155 \pm \\
0.9^{*}\end{array}$ & $\begin{array}{c}P= \\
0.002\end{array}$ & $\begin{array}{c}P= \\
0.03\end{array}$ & $\begin{array}{c}P= \\
0.35\end{array}$ \\
\hline $72 \mathrm{~h}$ & $\begin{array}{c}150 \pm \\
1.3\end{array}$ & $\begin{array}{c}155 \pm \\
1.3^{*}\end{array}$ & $\begin{array}{c}158 \pm \\
1.3^{*}\end{array}$ & $\begin{array}{c}P= \\
0.0001\end{array}$ & $\begin{array}{c}P= \\
0.39\end{array}$ & $\begin{array}{c}P= \\
0.05\end{array}$ \\
\hline 7 days & $\begin{array}{c}147 \pm \\
1.6\end{array}$ & $\begin{array}{c}154 \pm \\
1.6^{*}\end{array}$ & $\begin{array}{c}162 \pm \\
1.6^{*} \ddagger\end{array}$ & $\begin{array}{c}P= \\
0.0001\end{array}$ & & \\
\hline 14 days & $\begin{array}{c}150 \pm \\
2.3\end{array}$ & $\begin{array}{c}157 \pm \\
2.2\end{array}$ & $\begin{array}{c}164 \pm \\
2.2^{*}\end{array}$ & $\begin{array}{c}P= \\
0.002\end{array}$ & & \\
\hline
\end{tabular}

B

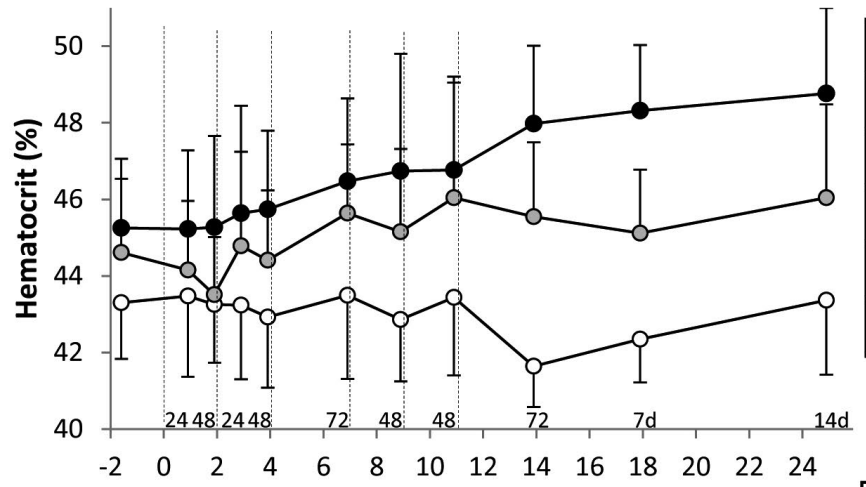

\begin{tabular}{|c|c|c|c|c|c|c|}
\hline & PLA & EPO20 & EPO50 & Group & $\begin{array}{c}\text { Occur } \\
\text { rence }\end{array}$ & $\mathrm{G} \times \mathrm{O}$ \\
\hline \multirow{2}{*}{$24 \mathrm{~h}$} & $\begin{array}{c}44.4 \pm \\
0.4\end{array}$ & $\begin{array}{c}44.3 \pm \\
0.4\end{array}$ & $\begin{array}{c}44.6 \pm \\
0.4\end{array}$ & $\begin{array}{c}P= \\
0.81\end{array}$ & $\begin{array}{c}P= \\
0.52\end{array}$ & $\begin{array}{c}P= \\
0.68\end{array}$ \\
\hline \multirow{2}{*}{$48 \mathrm{~h}$} & $\begin{array}{c}44.1 \pm \\
0.3\end{array}$ & $\begin{array}{c}44.6 \pm \\
0.3\end{array}$ & $\begin{array}{c}45.3 \pm \\
0.3^{*}\end{array}$ & $\begin{array}{c}P= \\
0.02\end{array}$ & $\begin{array}{c}P= \\
0.09\end{array}$ & $\begin{array}{c}P= \\
0.38\end{array}$ \\
\hline $72 \mathrm{~h}$ & $\begin{array}{c}43.4 \pm \\
0.4\end{array}$ & $\begin{array}{c}45.4 \pm \\
0.3^{*}\end{array}$ & $\begin{array}{c}46.5 \pm \\
0.3^{*}\end{array}$ & $\begin{array}{c}P= \\
0.0001\end{array}$ & $\begin{array}{c}P= \\
0.70\end{array}$ & $\begin{array}{c}P= \\
0.004\end{array}$ \\
\hline 7 days & $\begin{array}{c}42.9 \pm \\
0.5\end{array}$ & $\begin{array}{c}45.0 \pm \\
0.5^{*}\end{array}$ & $\begin{array}{c}47.9 \pm \\
0.5^{*} \ddagger\end{array}$ & $\begin{array}{c}P= \\
0.0001\end{array}$ & & \\
\hline \multirow{2}{*}{14 days } & $\begin{array}{c}44.0 \pm \\
\end{array}$ & $\begin{array}{c}45.9 \pm \\
0.7\end{array}$ & $\begin{array}{c}48.2 \pm \\
0.7^{*}\end{array}$ & $\begin{array}{c}P= \\
0.005\end{array}$ & & \\
\hline
\end{tabular}

C

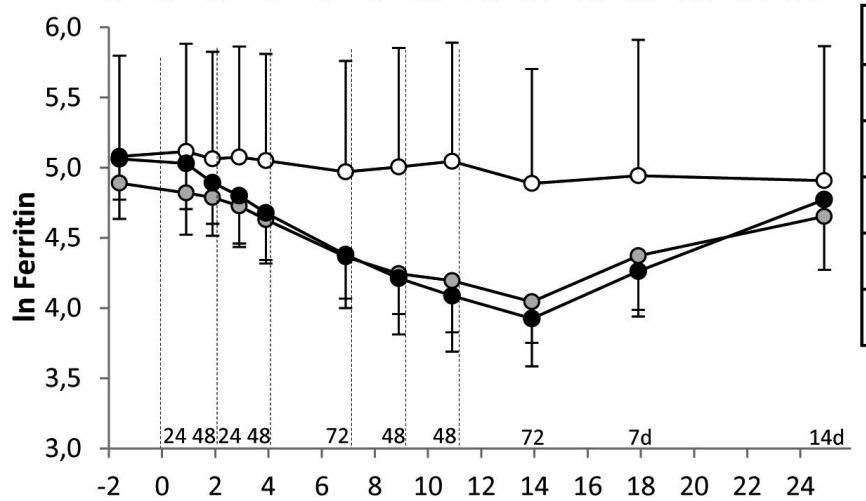

\begin{tabular}{|c|c|c|c|c|c|c|}
\hline & PLA & EPO20 & EPO50 & Group & $\begin{array}{c}\text { Occur } \\
\text { rence }\end{array}$ & $\mathrm{G} \times \mathrm{O}$ \\
\hline $24 \mathrm{~h}$ & $\begin{array}{c}5.02 \pm \\
0.03\end{array}$ & $\begin{array}{c}4.90 \pm \\
0.03^{*}\end{array}$ & $\begin{array}{c}4.86 \pm \\
0.03^{*}\end{array}$ & $\begin{array}{c}P= \\
0.001\end{array}$ & $\begin{array}{c}P= \\
0.001\end{array}$ & $\begin{array}{c}P= \\
0.08\end{array}$ \\
\hline \multirow{2}{*}{$48 \mathrm{~h}$} & $\begin{array}{c}4.97 \pm \\
0.03\end{array}$ & $\begin{array}{c}4.60 \pm \\
0.03^{*}\end{array}$ & $\begin{array}{c}4.41 \pm \\
0.03^{*} \ddagger\end{array}$ & $\begin{array}{c}P= \\
0.0001\end{array}$ & $\begin{array}{c}P= \\
0.0001\end{array}$ & $\begin{array}{c}P= \\
0.0001\end{array}$ \\
\hline $72 \mathrm{~h}$ & $\begin{array}{c}4.86 \pm \\
0.05\end{array}$ & $\begin{array}{c}4.33 \pm \\
0.05^{*}\end{array}$ & $\begin{array}{c}4.10 \pm \\
0.05^{*} \ddagger\end{array}$ & $\begin{array}{c}P= \\
0.0001\end{array}$ & $\begin{array}{c}P= \\
0.0001\end{array}$ & $\begin{array}{c}P= \\
0.06\end{array}$ \\
\hline 7 days & $\begin{array}{c}4.86 \pm \\
0.11\end{array}$ & $\begin{array}{c}4.52 \pm \\
0.11\end{array}$ & $\begin{array}{c}4.20 \pm \\
0.11^{*}\end{array}$ & $\begin{array}{c}P= \\
0.001\end{array}$ & & \\
\hline 14 days & $\begin{array}{c}4.83 \pm \\
0.09\end{array}$ & $\begin{array}{c}4.79 \pm \\
0.09\end{array}$ & $\begin{array}{c}4.71 \pm \\
0.09\end{array}$ & $\begin{array}{c}P= \\
0.66\end{array}$ & & \\
\hline
\end{tabular}

D

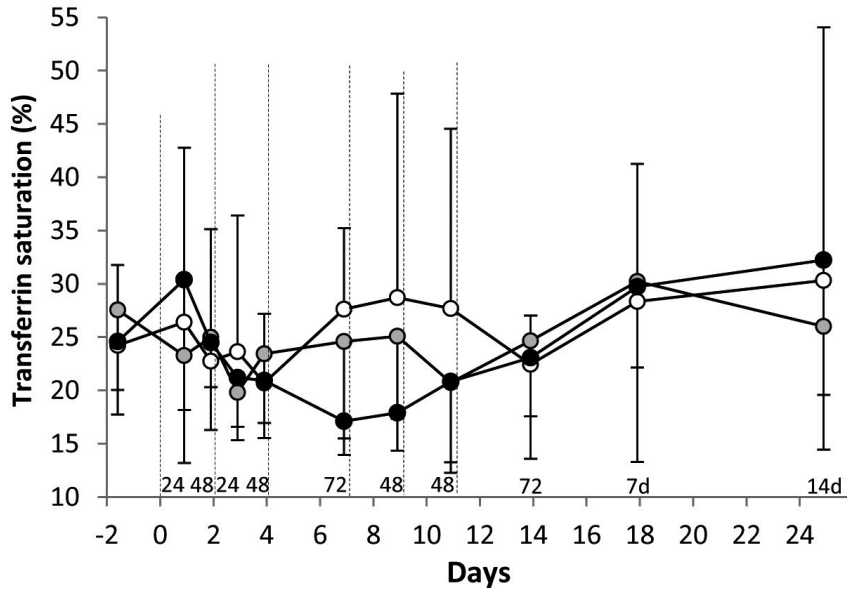

\begin{tabular}{|c|c|c|c|c|c|c|}
\hline & PLA & EPO20 & EPO50 & Group & $\begin{array}{c}\text { Occur } \\
\text { rence }\end{array}$ & $G \times 0$ \\
\hline $24 \mathrm{~h}$ & $\begin{array}{c}25.8 \pm \\
2.6\end{array}$ & $\begin{array}{c}20.2 \pm \\
2.6\end{array}$ & $\begin{array}{c}26.3 \pm \\
2.5\end{array}$ & $\begin{array}{c}P= \\
0.20\end{array}$ & $\begin{array}{c}P= \\
0.09\end{array}$ & $\begin{array}{c}P= \\
0.62\end{array}$ \\
\hline \multirow{2}{*}{$48 \mathrm{~h}$} & $\begin{array}{c}25.8 \pm \\
1.6\end{array}$ & $\begin{array}{c}22.1 \pm \\
1.6\end{array}$ & $\begin{array}{c}21.6 \pm \\
1.6\end{array}$ & $\begin{array}{c}P= \\
0.13\end{array}$ & $\begin{array}{c}P= \\
0.78\end{array}$ & $\begin{array}{c}P= \\
0.33\end{array}$ \\
\hline $72 \mathrm{~h}$ & $\begin{array}{c}25.6 \pm \\
1.6\end{array}$ & $\begin{array}{c}23.7 \pm \\
1.7\end{array}$ & $\begin{array}{c}20.5 \pm \\
1.6\end{array}$ & $\begin{array}{c}P= \\
0.09\end{array}$ & $\begin{array}{c}P= \\
0.88\end{array}$ & $\begin{array}{c}P= \\
0.07\end{array}$ \\
\hline 7 days & $\begin{array}{c}29.5 \pm \\
4.1\end{array}$ & $\begin{array}{c}28.3 \pm \\
4.1\end{array}$ & $\begin{array}{c}30.5 \pm \\
4.0\end{array}$ & $\begin{array}{c}P= \\
0.93\end{array}$ & & \\
\hline \multirow{2}{*}{14 days } & $\begin{array}{c}31.1 \pm \\
5.9\end{array}$ & $\begin{array}{c}24.7 \pm \\
6.0\end{array}$ & $\begin{array}{c}32.8 \pm \\
5.9\end{array}$ & $\begin{array}{c}P= \\
0.62\end{array}$ & & \\
\hline
\end{tabular}

Figure 2. Effects of repeated administration of very low to low doses of recombinant human erythropoietin on hematologic and iron parameters. (A-D) Blood hemoglobin concentration (A), hematocrit (B), serum concentration of ferritin (In transformed) (C) and transferrin saturation (D) before, during and after six injections of placebo $(n=8)$, recombinant human erythropoietin (rhEpo) $20 \mathrm{IU} / \mathrm{kg}$ (micro-dose) $(n=8)$ or rhEpo $50 \mathrm{IU} / \mathrm{kg}($ low dose) ( $n=8)$. Vertical dotted lines indicate injections. Baselines are means from duplicate blood samples collected on separated days. Blood sampling was repeatedly performed at $24 \mathrm{~h}(2 \mathrm{occurrences)}, 48 \mathrm{~h}$ ( 4 occurrences) and $72 \mathrm{~h}$ ( 2 occurrences) after an injection. Additional samples were obtained at 7 and 14 days after the last injection. Numbers above the abscissa line (i.e., $24,48,72,7 \mathrm{~d}$ and $14 \mathrm{~d}$ ) indicate these sampling times. Data are means \pm standard deviations. For each panel, the inserted table reports estimated marginal means \pm standard errors and P-values for the effect of the group (placebo, micro-dose, low dose), the occurrence (i.e., the number of samples at $24 \mathrm{~h}, 48 \mathrm{~h}, 72 \mathrm{~h}$, 7 days and 14 days, from 1 to 4$)$ and the group $\times$ occurrence $(\mathrm{G} \times 0)$ interaction. Multiple comparisons between groups at $24 \mathrm{~h}, 48 \mathrm{~h}$ or $72 \mathrm{~h}$ are reported in each table, *Denotes a difference from placebo and łdenotes a difference from micro-dose (see the Online Supplementary Material, Statistical analysis section). Epo: erythropoietin; ERFE: erythroferrone; PLA: placebo. EPO20: recombinant human erythropoietin 20 IU/kg; EPO50: recombinant human erythropoietin 50 IU/kg. 
development of a validated assay for human ERFE led to the demonstration that ERFE is increased in patients with $\beta$-thalassemia and in response to blood donation or administration of high doses of rhEpo. ${ }^{8}$ Moreover, serum ERFE levels were found to be elevated in patients with chronic kidney disease treated with $\mathrm{rhEpo}^{9}$ and in children affected by iron deficiency anemia. ${ }^{10}$ However, another study did not find increased ERFE levels in patients with chronic kidney disease. ${ }^{11}$ In addition, ERFE did not change in patients with reduced erythropoiesis caused by androgen deprivation therapy ${ }^{12}$ or in athletes exposed to altitude $^{13}$ and, unexpectedly, decreased in parallel with hepcidin in subjects experiencing expansion of hemoglobin mass $\left(\mathrm{Hb}_{\text {mas }}\right)$ due to exposure to altitude. ${ }^{14}$ The effect of accelerated erythropoiesis on ERFE in humans does, therefore, remain uncertain. Here, we tested the hypothesis that, in healthy humans, ERFE is a physiological erythroid regulator, i.e. it responds to moderate erythropoietic stimulation, such as very low rhEpo doses or exposure to high altitude.

\section{Methods}

\section{Study design}

For the rhEpo study, $\mathrm{Hb}_{\text {max }}$, indices of iron homeostasis and hematologic parameters were repeatedly measured in 24 healthy males given six injections (every second/third day) of saline (placebo), rhEpo $20 \mathrm{IU} / \mathrm{kg}$ (micro-dose) or rhEpo $50 \mathrm{IU} / \mathrm{kg}$ (low dose) Written informed consent to participation in the study was provided by all these subjects. The study (NCT03276910) was approved by the French ethics committee (CPP Est-III, EudraCT 2017-000375-82). For the high-altitude study, iron parameters were determined in 22 healthy subjects exposed to high altitude $(3800 \mathrm{~m})$ for $15 \mathrm{~h}$. Written informed consent to participation in the study was provided by all these subjects. The study (NCT02778659) was approved by the French ethics committee (CPP Sud-Est-III, EudraCT 2015-004512-38).

Details of the methods are available in the Online Supplementary Material.

\section{Results}

Three days after the last rhEpo injection, $\mathrm{Hb}_{\text {mas }}$ was higher in subjects treated with low-dose rhEpo than in those given the placebo (Figure 1A). In contrast, treatment with micro-doses of rhEpo did not induce significantly higher $\mathrm{Hb}_{\text {mas }}$ levels in comparison to those induced by placebo treatment. $\mathrm{Hb}_{\text {mass }}$ was not significantly altered following placebo treatment but nonetheless tended to decrease, possibly because of frequent blood sampling. Short treatment duration may otherwise explain the marginal change of $\mathrm{Hb}_{\text {mass }}$ following micro-doses of rhEpo. Unlike $\mathrm{Hb}_{\text {mass }}$, hemoglobin concentration and hematocrit progressively increased with both rhEpo doses (Figure 2A, B). As expected, circulating Epo levels increased after each injection, but rapidly declined, in particular after micro-dose treatment (Figure 1B). ERFE levels showed a significant dose-related increase after each injection, remaining above placebo levels for up to $48 \mathrm{~h}$ (micro-dose) or $72 \mathrm{~h}$ (low dose) and decreasing thereafter (Figure 1C). Following low-dose rhEpo treatment, ERFE reached levels similar to those found in patients with anemia induced by bleeding (see the Online Supplementary Material, Analyses section).
The pattern of variation of ERFE levels mirrored that of serum Epo (Figure 3A). Conversely, serum hepcidin decreased when Epo and ERFE rose, independently of the dose, and remained low as long as Epo and ERFE were above baseline values (Figure 1D). Both ERFE and hepcidin returned to placebo levels 1 week after the last injection. Interestingly, there was no cumulative effect of repeated rhEpo injections on ERFE levels (Figure 1C). Consistent with previous studies, ${ }^{3-5}$ the decrease in serum ferritin

A

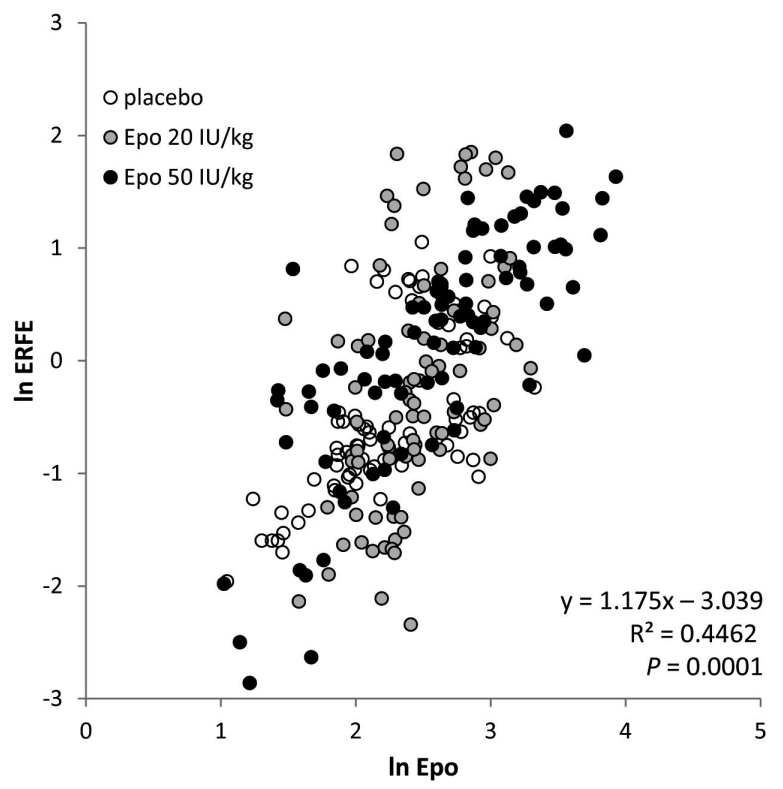

B

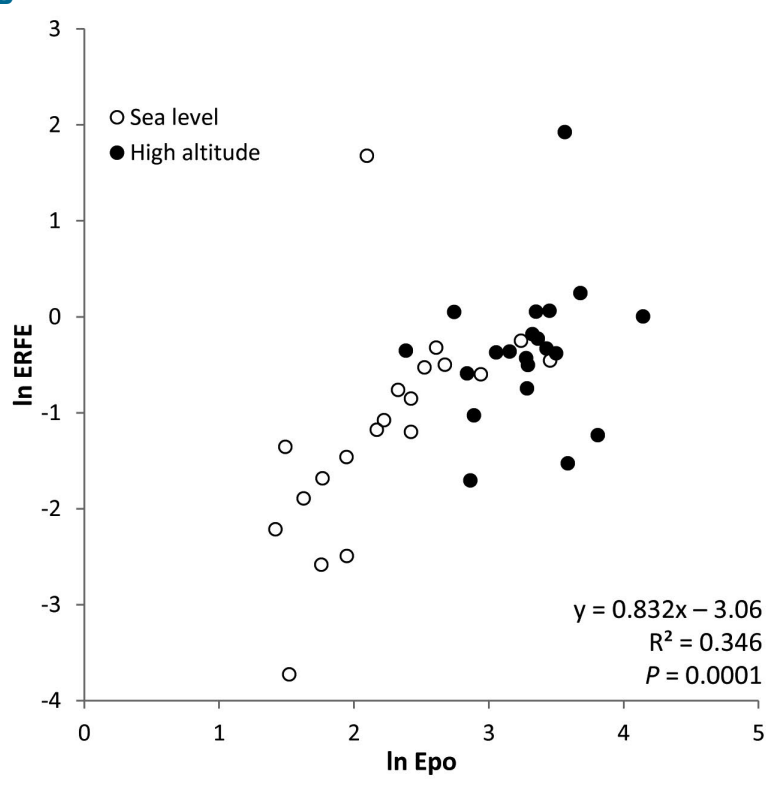

Figure 3. Relationships between erythroferrone and erythropoietin with recombinant human erythropoietin and high altitude. (A, B) Relationship between individual serum concentrations (In transformed) of erythroferrone (ERFE) and erythropoietin (Epo), before, during and after six injections of placebo, micro-dose or low-dose recombinant human erythropoietin (rhEpo) in healthy subjects (A), and at sea level and after $15 \mathrm{~h}$ of exposure to high altitude $(3800 \mathrm{~m})$ in healthy subjects $(B)$. Regression equations, coefficients of determination and $P$ values are reported in each panel. Relationships between hepcidin, Epo and ERFE during rhEpo injections are available in Online Supplementary Figure S2. 
with rhEpo was progressive (Figure 2C). In contrast, transferrin saturation (Tfsat) was not significantly altered by rhEpo injections (Figure 2D).

We also found concomitant increases in Epo and ERFE in healthy subjects exposed to a high altitude condition associated with $\mathrm{O}_{2}$ saturation of $85 \pm 3 \%$ (Figure 4A, B). The correlation between ERFE and serum Epo found at high altitude (Fig $3 \mathrm{~B}$ ) and with rhEpo treatment (Figure $3 A)$ suggests that hypoxia-related signaling is not directly involved in ERFE induction, as previously shown in mice. ${ }^{6}$ ERFE tended to increase more with micro-dose rhEpo than with exposure to high altitude $(P=0.22)$, whereas Epo increased less with the micro-dose injections than with exposure to high altitude $(P=0.04)$ (data not shown). We speculate that the shorter time of exposure to elevated Epo levels at high altitude ( $15 \mathrm{~h})$ versus micro-dose injections $(24 \mathrm{~h})$ may account for the observed trend. Tfsat, which was close to the level defining iron deficiency
A

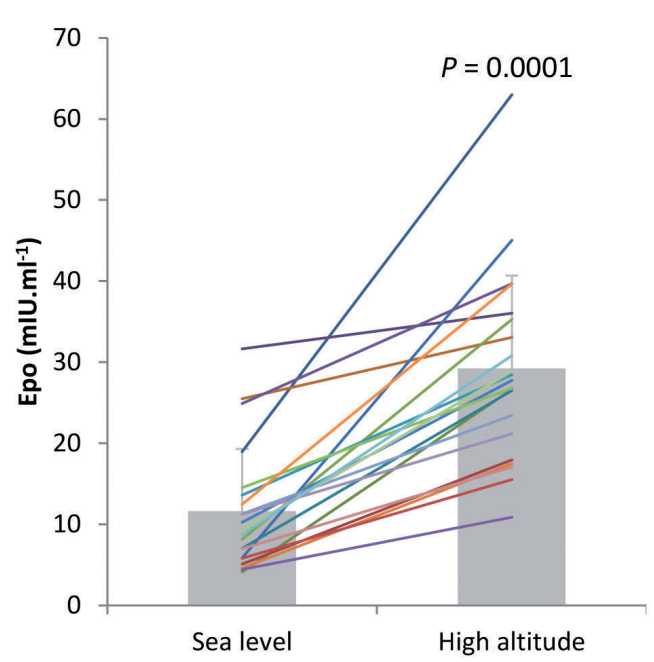

C

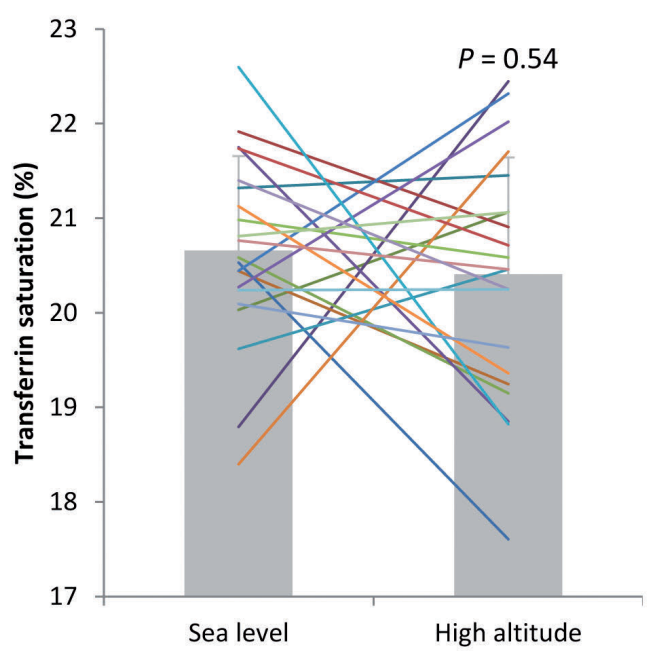

$E$

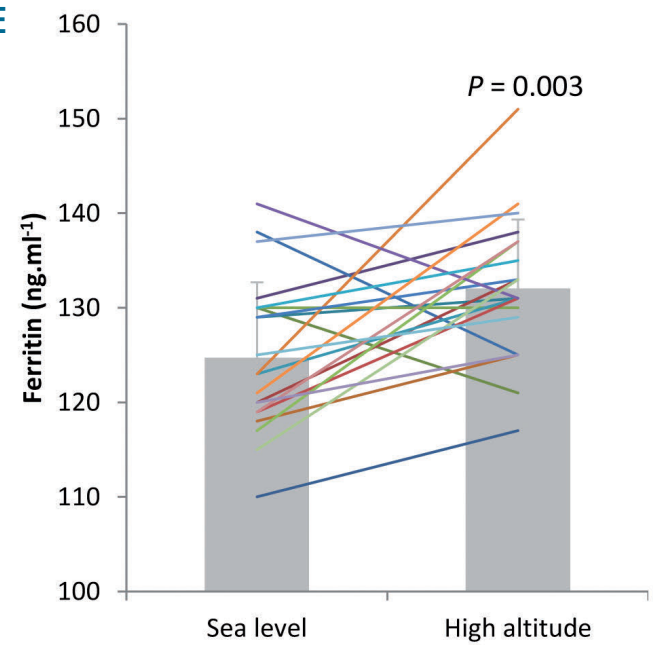

B

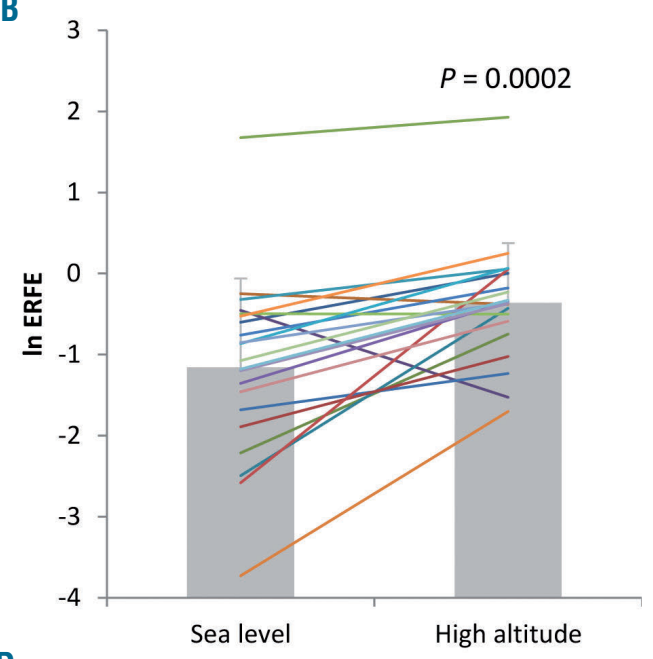

D

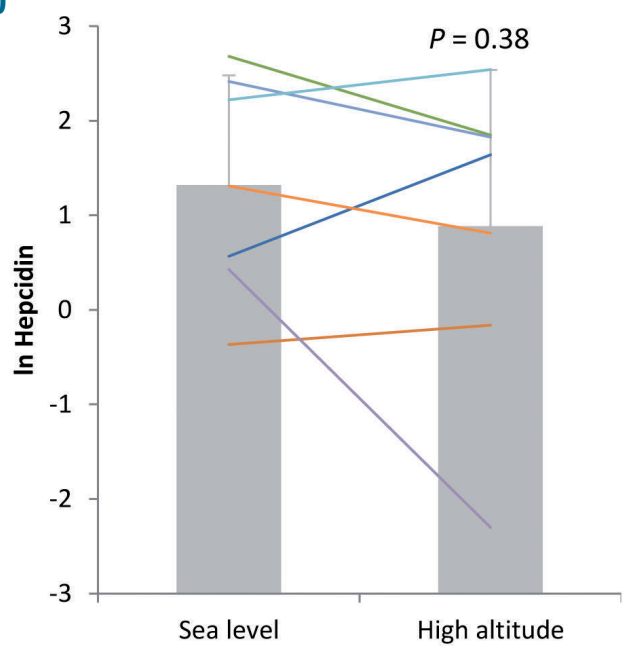

Figure 4. Effects of acute exposure to high altitude. Individual serum concentrations and means \pm standard deviations of erythropoietin $(n=21)(A)$, erythroferrone (In transformed, $n=21)(B)$, transferrin saturation $(n=22)(C)$, hepcidin (In transformed, $n=7)(D)$ and ferritin $(n=22)(E)$, at sea level and after 15 $\mathrm{h}$ of exposure to high altitude $(3800 \mathrm{~m}$ ). Of note, out of 22 subjects, $15 \mathrm{sub}$ jects had sea-level hepcidin concentrations which were below the detection limit; therefore, the hepcidin statistical analysis was performed on seven subjects. $P$ values denote differences between sea level and high altitude. Epo: erythropoietin; ERFE: erythroferrone. 
$(<20 \%)$, did not change (Figure 4C). Consistent with the low Tfsat, hepcidin concentration at sea level was below the detection limit in 15 subjects and was unchanged after exposure to high altitude in the subjects with detectable baseline values (Figure 4D). Lack of correlation between ERFE and hepcidin was previously found in patients with chronic kidney disease, in whom increased ERFE levels were not accompanied by lower hepcidin. ${ }^{9}$ In line with a previous report showing unaltered iron availability and no signs of inflammation at high altitude, ${ }^{15}$ the inflammatory marker interleukin- 6 was not affected by the subjects' exposure to high altitude $(1.28 \pm 1.04 \mathrm{pg} / \mathrm{mL}$ vs. $1.25 \pm 0.9$ $\mathrm{pg} / \mathrm{mL}$ at sea level), whereas the concentration of ferritin increased slightly (from $125 \pm 8$ to $132 \pm 7 \mathrm{ng} / \mathrm{mL}$ ), although remaining within the normal range (Figure $4 \mathrm{E}$ ).

\section{Discussion}

Recently, mouse studies have shown that acute rhEpo treatment downregulates hepcidin in an ERFE-independent manner by decreasing serum iron and Tfsat. ${ }^{16,17}$ Moreover, the demonstration that rhEpo administration also downregulates hepcidin in mice lacking ERFE ${ }^{18}$ suggests that prolonged erythropoietic stimulation inhibits hepcidin expression in mice by depleting iron stores, whereas ERFE represents an acute regulator of stress erythropoiesis. ${ }^{18}$ Conversely, the present results show that in healthy humans ERFE responds even to low Epo levels which are not associated with an expansion of $\mathrm{Hb}_{\text {mas }}$, a functional marker of erythropoietic response. ${ }^{19}$ This conclusion is also supported by our findings in a physiological condition such as high-altitude hypoxia (Figure 4). Furthermore, our data showing no alterations in Tfsat and a progressive decrease in ferritin with repeated rhEpo injections are consistent with the view that ERFE may inhibit hepcidin transcription directly in the absence of changes in serum and liver iron. In fact, the ERFE-hepcidin axis was affected early, i.e. $24 \mathrm{~h}$ after the first rhEpo injection, while other serum iron parameters were unchanged at that time, as $t$ test analysis showed no difference in ferritin between groups at 24 and $48 \mathrm{~h}$ after the first injection (see Online Supplementary Material, Statistical analysis section). However, it is well conceivable that under conditions of strong erythropoietic stimulation, such as in mice treated with high doses of rhEpo (8000 $\mathrm{IU} / \mathrm{kg}),{ }^{16-18}$ increased iron consumption for erythropoiesis leads to iron depletion and repression of hepcidin.

The introduction of the Athlete's Blood Passport ${ }^{20}$ has improved the detection of blood doping, although the Passport does have several limitations, ${ }^{21}$ in particular in detecting micro-dose rhEpo doping. ${ }^{22}$ A study in which
ERFE was measured in six subjects receiving relatively high doses of rhEpo or analogs, intravenously or subcutaneously, using an assay different from the one used in this study did not suggest that ERFE would be a reliable marker for rhEpo doping, ${ }^{23}$ although (while our manuscript was under revision) the same group reported that a different enzyme-linked immunosorbent assay was able to detect increased ERFE levels in the same samples. ${ }^{24}$ Conversely, increased erythropoiesis induced by training did not affect ERFE and hepcidin levels in runners. ${ }^{25}$ Our results demonstrate that ERFE is sensitive enough to flag even microdose rhEpo, correlates with Epo levels (Figure 3A, B) and has a detection window longer than that of Epo, thereby indicating that ERFE holds promise as a novel biomarker of doping for implementation in the ABP, although additional studies are required. In view of our results, ferritin or hepcidin could also be considered as potential biomarkers of the use of micro-dose rhEpo, although both factors may be confounded by iron supplementation, a legal practice commonly used by athletes.

In summary, the present results demonstrate that in healthy humans ERFE is promptly enhanced in response to moderately increased Epo levels and represses hepcidin in an iron-independent way. Assaying ERFE levels may provide additional analytical support for the fight against doping.

\section{Disclosures \\ No conflicts of interests to disclose.}

\section{Contributions}

$P R$ designed and coordinated the project, planned and performed experiments and co-wrote the manuscript. EG collected and interpreted data and co-wrote the manuscript. SR, DG and $A C$ collected and analyzed data. MR analyzed data and performed the statistical analysis, $A-K L, P B a, P B o, S V, G S$ and $M U$ collected data, CL analyzed data and revised the manuscript, CC provided clinical support, PS designed and coordinated the project, discussed the results and co-wrote the manuscript. GC conceived and coordinated the study, interpreted data and cowrote the manuscript. All authors discussed the results and commented on the manuscript.

\section{Acknowledgments}

The authors thank Dr. Catherine Mercier (Hospices Civils de Lyon) for expert statistical advice, as well as Dr. Jean-Pierre Herry, Dr. Alice Gavet and Laura Oberholzer for their assistance during the protocol. The work involving rhEpo administration was supported by a grant from Partnership for Clean Competition to GC. The altitude study was supported by the Fédération Française des Clubs Alpins et de Montagne and Fondation Petzl through grants to PBo.

\section{References}

1. Ganz T. Erythropoietic regulators of iron metabolism. Free Radic Biol Med. 2019;133:69-74.

2. Camaschella C, Pagani A. Advances in understanding iron metabolism and its crosstalk with erythropoiesis. $\mathrm{Br} \mathrm{J}$ Haematol. 2018;182(4):481-494.

3. Robach P, Recalcati S, Girelli D, et al. Alterations of systemic and muscle iron metabolism in human subjects treated with low-dose recombinant erythropoietin Blood. 2009;113(26):6707-6715

4. Ashby DR, Gale DP, Busbridge $M$, et al. Erythropoietin administration in humans causes a marked and prolonged reduction in circulating hepcidin. Haematologica. 2010;95(3):505-508.

5. Robach P, Recalcati S, Girelli D, et al. Serum hepcidin levels and muscle iron proteins in humans injected with low- or high-dose erythropoietin. Eur J Haematol. 2013;91
(1):74-84.

6. Kautz L, Jung G, Valore EV, Rivella S Nemeth E, Ganz T. Identification of erythroferrone as an erythroid regulator of iron metabolism. Nat Genet. 2014;46(7): 678-684.

7. Arezes J, Foy N, McHugh $\mathrm{K}$, et al. Erythroferrone inhibits the induction of hepcidin by BMP6. Blood. 2018;132(14): 1473-1477.

8. Ganz T, Jung G, Naeim A, et al Immunoassay for human serum erythrofer 
rone. Blood. 2017;130(10):1243-1246.

9. Hanudel MR, Rappaport M, Chua K, et al. Levels of the erythropoietin-responsive hormone erythroferrone in mice and humans with chronic kidney disease. Haematologica. 2018;103(4):e141-e142.

10. El Gendy FM, El-Hawy MA, Shehata AMF, Osheba HE. Erythroferrone and iron status parameters levels in pediatric patients with iron deficiency anemia. Eur J Haematol. 2018;100(4):356-360.

11. Honda H, Kobayashi Y, Onuma S, et al. Associations among erythroferrone and biomarkers of erythropoiesis and iron metabolism, and treatment with long-term erythropoiesis-stimulating agents in patients on hemodialysis. PLoS One. 2016;11(3):e0151601.

12. Gagliano-Jucá T, Pencina KM, Ganz T, et al. Mechanisms responsible for reduced erythropoiesis during androgen deprivation therapy in men with prostate cancer. Am J Physiol Endocrinol Metab. 2018;315(6): E1185-E1193.

13. Garvican-Lewis LA, Vuong VL, Govus AD, et al. Intravenous iron does not augment the hemoglobin mass response to simulated hypoxia. Med Sci Sports Exerc.
2018;50(8):1669-1678.

14. Hall R, Peeling P, Nemeth E, Bergland D, McCluskey WTP, Stellingwerff T. Single versus split dose of iron optimizes hemoglobin mass gains at $2106 \mathrm{~m}$ altitude. Med Sci Sports Exerc. 2019;51(4):751-759.

15. Talbot NP, Lakhal S, Smith TG, et al. Regulation of hepcidin expression at high altitude. Blood. 2012;119(3):857-860.

16. Artuso I, Pettinato $M$, Nai A, et al. Transient decrease of serum iron after acute erythropoietin treatment contributes to hepcidin inhibition by ERFE in mice. Haematologica. 2019;104(3):e87-e90

17. Mirciov CSG, Wilkins SJ, Hung GCC Helman SL, Anderson GJ, Frazer DM. Circulating iron levels influence the regulation of hepcidin following stimulated erythropoiesis. Haematologica. 2018;103(10): 1616-1626.

18. Coffey R, Sardo U, Kautz L, Gabayan V, Nemeth E, Ganz T. Erythroferrone is not required for the glucoregulatory and hematologic effects of chronic erythropoietin treatment in mice. Physiol Rep. 2018;6(19):e13890

19. Siebenmann C, Keiser S, Robach P, Lundby C. CORP: the assessment of total hemoglo- bin mass by carbon monoxide rebreathing. J Appl Physiol (1985). 2017;123(3):645-654.

20. Cazzola M. A global strategy for prevention and detection of blood doping with erythropoietin and related drugs. Haematologica. 2000;85(6):561-563.

21. Jelkmann W, Lundby C. Blood doping and its detection. Blood. 2011;118(9):23952404.

22. Ashenden M, Gough CE, Garnham A, Gore CJ, Sharpe K. Current markers of the Athlete Blood Passport do not flag microdose EPO doping. Eur J Appl Physiol. 2011;111(9):2307-2314

23. Leuenberger N, Bulla E, Salamin O, et al Hepcidin as a potential biomarker for blood doping. Drug Test Anal. 2017;9(7):10931097.

24. Cuevas KR, Schobinger C, Gottardo E, et al. Erythroferrone as a sensitive biomarker to detect stimulation of erythropoiesis. Drug Test Anal. 2020;12(2):261-267.

25. Moretti D, Mettler S, Zeder C, et al. An intensified training schedule in recreational male runners is associated with increases in erythropoiesis and inflammation and a net reduction in plasma hepcidin. Am J Clin Nutr. 2018;108(6):1324-1333 